\title{
The Environmental Impacts and Economic Benefits on Comprehensively Promoting Alternative Fuel Buses in China: Life-Cycle and Scenario Analysis Based on LEAP Model
}

\author{
Siting Xie \\ College of Economics, Jinan University, Guangzhou, China \\ Email: xiesiting1993@163.com
}

How to cite this paper: Xie, S. T. (2019). The Environmental Impacts and Economic Benefits on Comprehensively Promoting Alternative Fuel Buses in China: Life-Cycle and Scenario Analysis Based on LEAP Model. Journal of Geoscience and Environment Protection, 7, 99-121.

https://doi.org/10.4236/gep.2019.74007

Received: February 19, 2019

Accepted: April 15, 2019

Published: April 18, 2019

Copyright $\odot 2019$ by author(s) and Scientific Research Publishing Inc. This work is licensed under the Creative Commons Attribution International License (CC BY 4.0).

http://creativecommons.org/licenses/by/4.0/

\begin{abstract}
With the continuous development of urban public transportation, the harmful GHG emissions and pollutants generated by itself and the consequent issues such as the losses of residents' health, economic value and residents' welfare have become the focus of social attention. In order to study the impacts of promoting new energy vehicles on public transportation pollution mitigation and residents' health benefits, this paper adopts the LEAP model to build some scenarios that fulfill different development needs to quantitatively analyze the ownership of new energy buses, the reduction of pollutants and the losses of residents' health welfare. It is concluded that promoting new energy buses comprehensively can significantly reduce the emissions of atmospheric pollutants and the economic losses of residents' health, but cannot fully realize the targets of greenhouse gas reduction under Life Cycle Analysis.
\end{abstract}

\section{Keywords}

New Energy Buses, Emission Mitigation, Economic Benefits, Life-Cycle Analysis, Scenario Analysis

\section{Introduction}

\subsection{Fast-Growing of and Pollutant Emissions from China's Road Transport Sector}

Facing the severe challenges of the global resource crisis and environmental pollution, all the countries are actively seeking countermeasures to achieve the dual mandate of environmental protection and social economic development. At 
present, exhaust emission of transport sector has become an important source of air pollution in China, especially in the first-tier cities such as Beijing, Shanghai, and eastern densely populated areas. The contribution of mobile sources to fine particulate matter $\left(\mathrm{PM}_{2.5}\right)$ concentrations is as high as $20 \%$ to $40 \%$. In 2016, China's motor vehicles exhaust emission was initially approved at 44.725 million tons, including carbon monoxide (CO) of 34.393 million tons, nitrogen oxides $\left(\mathrm{NO}_{\mathrm{X}}\right)$ of 5.778 million tons, and particulate matter (PM) of 0.534 million tons ${ }^{1}$. In recent years, in order to alleviate the road-transport sector's environmental pollution problems, China has adopted a two-pronged approach. On the one hand, the government adopts restrictive measures, such as some of first-tier cities to adopt "traffic restriction" and "restricted purchase" measures; on the other hand, it adopts encouraging measures, such as implementing public transport priority polices, and vigorously developing large-capacity public transport like BRT and rail transit ${ }^{2}$. The total length of public steam tram lines in 2017 reached 559,000 kilometers, an increase of 30,000 kilometers compared with 2016, which is four times the total mileage of highways nationwide ${ }^{3}$. The rapid development of urban road public transportation can fulfill the increasing traffic demand, and mitigate somewhat the overall pollution problem of the road traffic department compared with private transportation.

However, road transport, including urban public transportation, mainly uses the traditional fossil energy at this stage (such as gasoline and diesel). According to the official website of the Ministry of Transport of China ${ }^{4}$, in 2015, the number of public standard operating buses was 561,800 units, including new energy buses that account for about $20 \%$. Fossil energy consumption in internal combustion engines is the major cause of air pollution, haze and photochemical smog. Since urban public transportation is mostly distributed in densely populated areas, $\mathrm{PM}_{2.5}, \mathrm{NO}_{\mathrm{X}}$ and other polluting gases in the exhaust emissions would immediately affect human health and quality of life that could negatively influence economic growth and residents' welfare. With the continuous development of urban public transportation, the harmful GHG (Greenhouse Gas, GHG) emissions and pollutants generated by itself and the consequent issues such as the losses of residents' health, economic value and residents' welfare have become the focus of social attention.

In order to curb harmful GHG emissions and pollutants in the road transport sector, improve the ecological environment, and realize the sustainable development, China has vigorously supported the technology research and marketing promotion of new energy vehicles in recent years, which has made great progress. Especially in the aspect of urban buses, China proposed the "863-plan"

${ }^{1}$ Data Sources: China Vehicle Environmental Management Annual Report 2017, Ministry of Environmental Protection of The People's Republic of China.

${ }^{2}$ Source: The 13 th Five-Year Development Outline of Urban Public Transportation, Ministry of Transport of the People's Republic of China.

${ }^{3}$ Data Sources: Public Transport Big Data Analysis Report of China's Major Cities (the first halt of 2017), amap.com.

${ }^{4}$ URL: http://zizhan.mot.gov.cn, Ministry of Transport of China. 
in the 1990s, which suggested to step up efforts to develop urban environmental-friendly buses. At the beginning of the century, the "10th Five-Year Plan" dedicated electric buses inventive project. The "11th Five-Year Plan" proposed increasing technology research and development of alternative fuel buses, and further promote the industrialization process of electric vehicles. In 2009, electric vehicle demonstration and application project that named the "Ten Cities and Thousand Vehicles" was launched. At present, from the perspective of technology research, industrialization and commercialization, China's new energy vehicles are mainly concentrated on hybrid vehicles and pure electric vehicles (as shown in Figure 1), which both have high feasibility and economy in energy saving and environmental protection and application. Hybrid vehicles and electric vehicles were expected to be the mainstream of new energy vehicles in the next stage ${ }^{5}$.

Therefore, the urban public transportation sector, especially the new energy buses, is an important demonstration of promoting new energy vehicles in China. In order to study the impacts of promoting new energy vehicles on public transportation pollution mitigation and residents' health benefits, this paper adopt the LEAP model ${ }^{6}$ (Long Range Energy Alternatives Planning System) to build some scenarios that fulfil different development needs to quantitatively analyze the ownership of new energy buses, the reduction of pollutants and the losses of residents' health welfare. It is an urgent and critically important to comprehensively describe the opportunities and impacts of actively seeking energy security and achieving emission mitigation of pollutants.

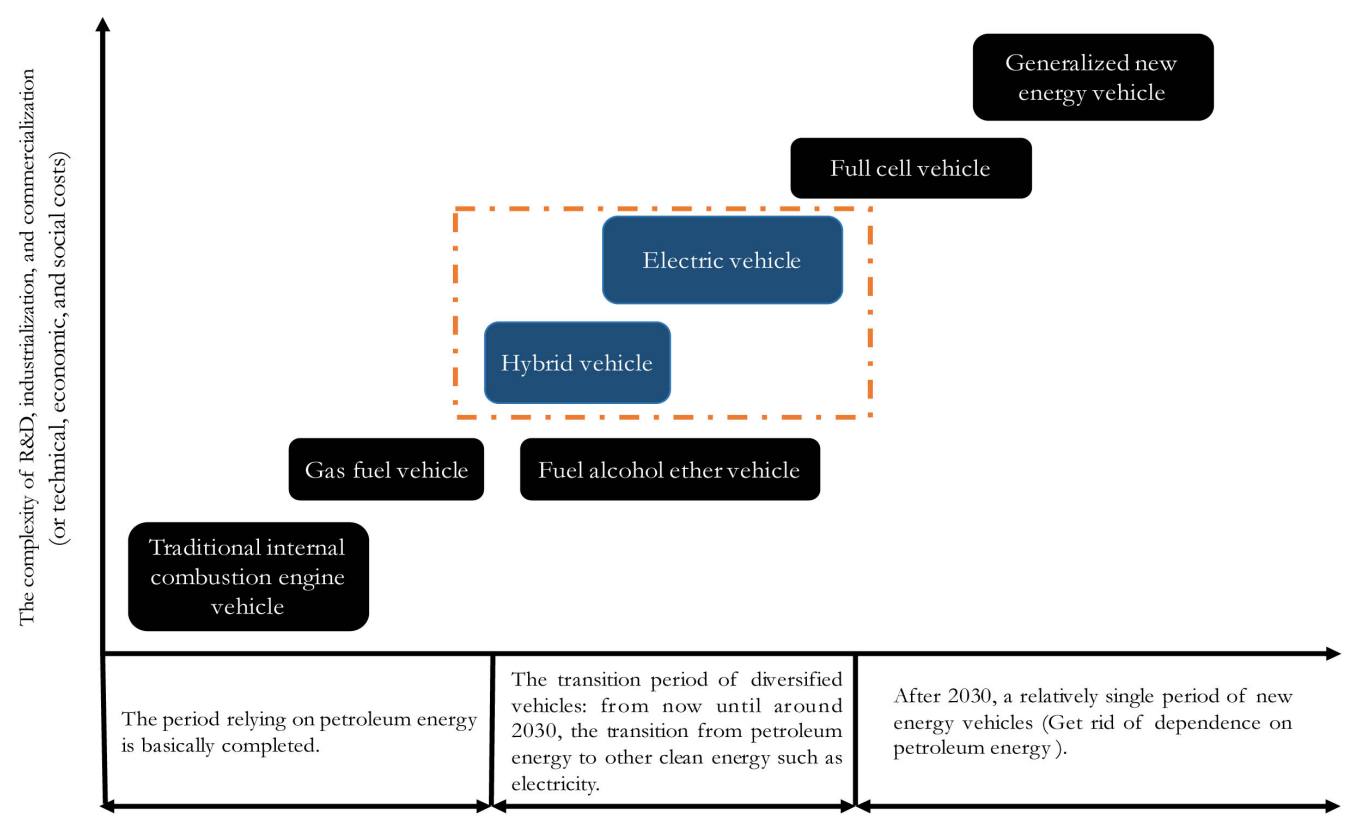

Figure 1. Panorama of China's new energy vehicle industry development route.

${ }^{5}$ URL: http://auto.gasgoo.com/topic/newenergy/, Current status and prospects of new energy vehicles.

${ }^{6}$ Official website: http://www.energycommunity.org/ or http://www.sei-us.org/. 


\subsection{Literature Review}

The rapid development of public transportation in various countries has generated sharp-increasing energy consumption, ever-growing pollutant emissions, and substantial losses to residents' health welfare. Therefore, several scholars have conducted a large number of studies on the analysis of energy saving and emission mitigation potential of public transportation, the evaluation and optimization of transport sector policy and the assessment of residents' health welfare. In the term of pollution measurement and policy evaluation and optimization, many earlier studies used the LEAP model to analyze the energy conservation and emission mitigation policies formulated by the highway and railway passenger transport departments in different cities and concluded that controlling private cars, fuel economy management and fuel taxation are the three most effective measures to achieve the reduction goal (Bose \& Srinivasachary, 1997; Yan \& Crookes, 2009). Some studies used scenario analysis to assess the impact of pollutant emissions from China's transport sector on air quality under different emission standards, and found that various pollutant emissions will be reduced more than $50 \%$ in the context of implementing strict emission standards by 2020 , which will greatly improve the air quality of China and even East Asia (Saikawa et al., 2011). Moreover, many studies focus on the vehicle emission factor and establishing pollution emission inventories for specific technology pathways, in order to quantitatively estimate the CO, $\mathrm{HC}, \mathrm{NO}_{\mathrm{x}}$ and $\mathrm{PM}_{2.5}$ emissions (He, 2015; Fan et al., 2016).

Promoting energy-saving vehicles as one of the important methods of energy conservation and emission mitigation in the public transport sector is an inevitable trend in the future development. Domestic and foreign scholars carried out in-depth studies on upgrading energy-saving vehicles, improving energy-using efficiency and exploring emission mitigation potentials. Researches indicated that considering the various factors such as oil prices, subsidy policies, alternative energy vehicles technology and prospective vehicles ownership, widespread use of alternative energy vehicles in urban transportation can effectively reduce $\mathrm{CO}_{2}$ and other pollutant emissions, and the road transport sector should increase the implementation to simultaneously promote pure electric vehicles (EVs) and hybrid (HEVs) vehicles in the future (Brady \& O'Mahony, 2011; Pasaoglu et al., 2012; Chen \& He, 2013). However, some scholars are skeptical about the mitigation efficiency of alternative energy vehicles. From the perspective of the Life Cycle Analysis, alternative energy vehicles instead of fossil energy vehicles cannot fully achieve the goal of energy saving and emission mitigation based on China's current coal-fired power generation ratio (Kong et al., 2012). As alternative energy buses are the main targets of promoting new energy vehicles, scholars also conduct in-depth research on the economical efficiency of them. Research suggests that combining with ownership costs, energy consumption during the whole life cycle and losses caused by pollutant emissions, higher financial subsidies can make up for the difference in the social costs between conventional diesel buses (CDBs) and hybrid buses (HEVs), and after entering the regionalization promotion stage, the costs during the whole life cycle of 
HEVs will be lower than CDBs (Ou et al., 2009).

Increasing traffic demand not only leads to a rapid increase in pollutant emissions from the transportation sector, but also a serious threat to economic development and residents' health. Therefore, residents' health levels would be one of important indicators to assess the effects of transport policy measures. In general, the comprehensive analysis framework of health benefits includes three steps: calculating the air quality concentration, estimating the physical losses of residents' health caused by air pollutants, and evaluating economic losses of residents' health. Firstly, the models of estimating the pollutant emissions from various policy paths has evolved from a simple first-generation to a complex third-generation model. Scholar had used Model-3/CMAQ (Community Multi-Scale Air Quality model) to study the effects of five kinds of vehicle emission control measures on air quality in the Pearl River Delta region in China. Results point out that multiple pollutants mixed and specific regional pollution control strategies are necessary (Che et al., 2011). Secondly, literature in the field of epidemiology has confirmed that air pollution can increase the risk of lung cancer, respiratory diseases, and cardiovascular disease. In view of the debate about the existence of threshold, most of the literature uses linear exposure-response functions and zero threshold hypothesis to estimate the physical losses of residents' health, which are widely used in health risk assessment research. Several studies quantify the impact of major atmospheric pollutants on residents' total mortality, respiratory diseases daily mortality and cardiovascular disease daily mortality etc. (Quah \& Boon, 2003; Chen, 2013; Liu et al., 2014). Finally, based on the economic perspective, the amount of physical loss is converted into monetized loss. In the field of health statistics, the existing assessment methods mainly include cost of illness method (COI) and willingness to pay method (WTP). Study uses synthesized evaluation method to estimate the health impacts and economic costs of China's road transport. The results show that total health losses of air pollution caused by Beijing transportation during 2004-2008 are about $0.58 \%$ of Beijing's GDP (Guo et al., 2010).

In summary, the existing literature only focuses on the research of energy saving and carbon mitigation in public transportation, and ignore to do a comprehensive research on the main pollutant emissions of vehicle exhaust. At the same time, it is lack to do a systematic research on the transmission mechanism from pollutant emission mitigation of alternative energy vehicles to residents' health benefits. This paper analyzes the future trends of alternative energy bus ownership and pollutant emissions under different scenarios in China's development plan. Meanwhile, study simultaneously calculates the economic benefits of promoting alternative energy buses on residents' health benefits.

\section{Methodology}

\subsection{Model Structure}

\subsubsection{Pollutant Emissions Accounting of Buses}

1) Pollutant emissions accounting during driving 
The LEAP model, a bottom-up energy-environment accounting tool based on scenario analysis, is mainly used to evaluate the effects of energy technologies, alternative energy programs and energy initiatives plans. The central concept of the LEAP model is the end-use-driven scenario analysis. It includes an integrated energy system accounting framework that can considers both demand-side and supply-side technologies and simultaneously assesses the overall impact on the system.

This model sets 2014 as the base year, and the main classification of bus vehicles is shown in Table 1. The ethanol gasoline for vehicles is determined according to Ethanol Gasoline for Motor Vehicles (E10) (GB 18351-2017). The ratio of fuel to gasoline is determined by reference to the existing research (Thomas, 2009).

In the model, the direct energy consumption of the buses is determined by several factors:

$$
E C_{t}=\sum \text { stock }_{i, j, t} \times F E_{i, j, t} \times D T_{i, j, t}
$$

where $E C_{t}$ is the energy consumption for the given year $t, i$ is the type of bus; $j$ is the fuel type used by the bus; $s_{\text {tock }} k_{i, j}$ is bus inventory of bus type $i$ using fuel type $j$ in the given year $t, F E_{i, j, t}$ is the average on-road fuel economy of bus type $i$ using fuel type $j$ in the given year $t, D T_{i, j, t}$ is the average annual traveled mileage of bus type $i$ using fuel type $j$ in the given year $t$.

Among them, the bus inventory is determined by the following factors:

$$
\begin{gathered}
\text { stock }_{i, j, t}=\sum_{\text {stock }_{i, j, t-1}} \times \text { SurRat }_{v, i}+\text { Sale }_{i, j, t} \\
\text { Allstock }_{t}=\sum \text { stock }_{i, j, t}
\end{gathered}
$$

where $v$ indicates the year when the bus is put into use; SurRat ${ }_{v, i}$ is the retention rate of bus type $i$ after $v$ years; Sale $_{i, j, t}$ is the sales volume of bus type $i$ using fuel type $j$ in the given year $t$, Allstock $_{t}$ is the bus possession for the given year $t$.

2) Pollutant emissions accounting under Life Cycle Analysis

New energy buses discharge less pollutants or even can achieve zero emissions during driving. But as China's power industry is still dominated by coal-fired

Table 1. China's bus vehicles classification.

\begin{tabular}{ccc}
\hline Vehicle Technology & Model & Fuel type \\
\hline Conventional energy & Gasoline buses & Gasoline \\
& Diesel buses & Diesel \\
Baving energy & Bioethanol-gasoline buses & 10\% Bioethanol + 90\% Gasoline \\
& LPG & Liquefied petroleum gas \\
LNG/CNG & Natural gas \\
Hew energy & Hybrid buses & $70 \%$ Gasoline $+30 \%$ Electricity \\
& Battery electric buses & Electricity
\end{tabular}

CNG-Compressed Natural Gas; LPG-Liquefied Petroleum Gas; LNG-Liquefied Natural Gas. 
units, emission mitigation effect of new energy buses is still disputed. This study used Life Cycle Analysis (LCA) to assess the potential impact of products' whole life cycle. The main life cycle of fuel mainly consists of two parts: the one is from well to pump (WTP), involving the extraction and transportation of raw materials, production and transportation of fuel etc.; and another one is from pump to wheel (PTW), which is related to fuel consumption and emissions. Limited by data sources, this study only conducts a full life cycle assessment of conventional buses and new energy buses.

The pollutant emissions of the buses can be calculated by the following formula:

$$
\text { Emission }_{i, j, k, t}=E C_{t} \times \text { EmiRat }_{i, j, k}+E C_{t} \times \mu_{j} \times \text { Emifac }_{j, k}
$$

where $k$ is the type of pollutant emissions, which includes greenhouse gas carbon dioxide $\mathrm{CO}_{2}$ and pollutants such as carbon monoxide $\mathrm{CO}$, nitrogen oxides $\mathrm{NO}_{\mathrm{x}}$ and particulate matter $\mathrm{PM}_{10}$; EmiRat ${ }_{i, j, k}$ is the emission factor of pollutant $k$ by the bus type $i$ using fuel type $j ; \mu_{j}$ is the energy consumption caused by unit fuel type $j$ Emifac $_{j, k}$ is the emission factor of pollutant $k$ discharged by fuel type $j$.

\subsubsection{Relationship between Buses Pollutant Emissions and Air Quality}

This study uses Box Model to establish the connection between buses pollutant emissions and air quality. The Box Model assumes that the simulated environment has uniform atmospheric conditions, and the chemical reaction mechanism of the pollutants is simplified. The pollutants in each period are completely purified in the current issue, which means that there are no cumulative pollutant emissions. The current air pollutant concentration can be calculated using the following formula:

$$
c=b+\frac{S \times L}{u \times H}
$$

where $c$ is the atmospheric pollutants concentration $\left(\mu \mathrm{g} / \mathrm{m}^{3}\right) ; b$ is the background concentration of pollutants $\left(\mu \mathrm{g} / \mathrm{m}^{3}\right)$, that is, there is natural gas concentration without any human activities; $S$ is the emission rate of pollutants $\left(\mu \mathrm{g} / \mathrm{s} \cdot \mathrm{m}^{2}\right) ; L$ is the length $(\mathrm{m}) ; u$ is the average wind speed $(\mathrm{m} / \mathrm{s}) ; H$ is the height of the box $(\mathrm{m})$.

$$
\frac{S_{2}}{S_{1}}=\frac{C_{2}-b}{C_{1}-b}
$$

where $S_{1}$ and $S_{2}$ respectively represent the reference emission rate and the future emission rate of pollutants $\left(\mu \mathrm{g} / \mathrm{s} \cdot \mathrm{m}^{2}\right) ;$ Emission $_{1} /$ Emission $_{2}$ means the ratio of the reference emission to the future emission under the assumption of uniform discharge of pollutants, which can be equated with $S_{1} / S_{2} . C_{1}$ and $\mathrm{C}_{2}$ respectively represent the reference concentration and the future concentration of air pollutants $\left(\mu \mathrm{g} / \mathrm{m}^{3}\right)$.

\subsubsection{Impact of Air Pollutantson Residents' Health Losses}

When the air pollution concentration is determined, the physical quantity of the 
resident's health losses can be quantified by the epidemiological exposure-response function. The resident's health losses are determined by three factors: the concentration of pollutants, the exposure-response coefficients between health outcome and pollutants, and the exposed population:

$$
\text { Case }_{i, j}^{\text {Morb }}=E R_{i, j} \times C_{j} \times P
$$

where $E R_{i, j}$ stand for the exposure-response coefficients between health outcome and the pollutant; $C_{j}$ is the pollutant concentration; $P$ is the exposed population. After obtaining the physical quantity of residents' health losses, we use three assessment methods: WTP (Willingness to Pay), COI (Cost of Illness) and VSL (Value of Statistical Life) to calculate the economic losses of unit resident, and thus evaluates the economic value of promoting new energy buses.

\subsection{Data}

\subsubsection{Stock and Sales Volume of Buses in China}

This study selected 2014 as the basic year. Since there is no official data on the annual sales volume of buses, the sales growth rate in this study varies according to the scenario (as shown in Table 2).

\subsubsection{Fuel Economy, Annual Mileage and Vehicle Survival Rate}

The fuel economy standard of heavy-duty diesel vehicles in China is relatively late, and the related research is relatively rare. This study cites the average fuel economy of 29 China IV diesel buses, $34 \mathrm{~L} / 100 \mathrm{~km}$ as the benchmark of diesel buses in the basic year. For natural gas buses, the actual testing results of 9 CNG buses show that the fuel economy of the natural gas buses is $15 \%$ lower than that of the diesel buses. Also according to the available testing data under the conservative setting, the fuel economy of battery electric buses and hybrid buses is $180 \%$ and $20 \%$ higher than that of diesel buses, respectively. The fuel economy of ethanol gasoline is $90 \%$ of gasoline (Wang, 2015) (as shown in Table 3).

Due to the lack of official statistics, the annual mileage of basic year is determined by existing research (Guo et al., 2007; He et al., 2005; Wang et al., 2007a; Yan, 2008). We select 35,000 kilometers as the bench mark. Each bus has a service age of 17 years. To make the data closer to reality, we assume that each bus

Table 2. Fuel economy, annual mileage and vehicle survival rate.

\begin{tabular}{cccc}
\hline Vehicle type & Fuel economy $(\mathrm{L} / 100 \mathrm{~km})$ & Annual mileage $(\mathrm{km})$ & Age (years) \\
\hline Gasoline buses & 35.02 & 35,000 & 17 \\
Diesel buses & 34 & 35,000 & 17 \\
LNG/CNG & 44.2 & 35,000 & 17 \\
Bioethanol-gasoline buses & 31.52 & 35,000 & 17 \\
Hybrid buses & 28.33 & 35,000 & 17 \\
Battery electric buses & 12.14 & 35,000 & 17 \\
\hline
\end{tabular}

Source: The data of fuel economy and annual mileage is quoted from the earlier studies and obtained by proportional conversion (Wang, 2015; Ou et al., 2010). 
Table 3. Stocks of buses in China (2010-2014).

\begin{tabular}{cccccc}
\hline Vehicle type/Year & 2010 & 2011 & 2012 & 2013 & 2014 \\
\hline Gasoline buses & 33,917 & 27,959 & 23,778 & 17,183 & 13,294 \\
Diesel buses & 290,271 & 304,215 & 306,465 & 302,428 & 279,927 \\
Bioethanol-gasoline buses & 13,920 & 12,549 & 9735 & 7978 & 4600 \\
LPG & 7535 & 9500 & 8884 & 8385 & 8408 \\
LNG/CNG & 69,943 & 89,432 & 110,907 & 149,531 & 183,953 \\
Hybrid buses & 1970 & 6613 & 11,704 & 19,186 & 29,320 \\
Battery electric buses & 957 & 1218 & 1722 & 3050 & 7297 \\
Other & 2007 & 1680 & 1696 & 1888 & 2004 \\
Total & 420,520 & 453,266 & 474,891 & 509,629 & 528,803 \\
\hline
\end{tabular}

Source: China Communications Statistical Yearbook (2010-2014). Ministry of Transport of the People's Republic of China. Since the statistics of the dual fuel vehicles are not classified, and the application is less. At present, the dual-fuel buses mainly used in China mainly use CNG as an alternative fuel, so the dual-fuel vehicles are classified into LNG vehicles. Considering that LNG and CNG energy consumption and emissions are basically the same, no distinction is made here.

must adhere to the degradation rate, which follows an exponential function: $S_{t}=S_{t-1} \mathrm{e}^{p t}$ (where $p$ is the parameter. $t$ is the usage time).According to the age of different buses, we set the mileage for the last year to be 0 . Therefore, the exponential function in the degradation profile is:

$$
S_{t}=S_{t-1} \cdot \mathrm{e}^{-0.045 t}
$$

where $S$ represents the share of the buses; $t$ represents the age of the buses.

In the LEAP model, the survival profile is used to describe the survival rate of the different life cycle stages. Once the bus has reached the end of useful age or mileage limit, it must be scrapped. If the bus has reached the end of useful age and does not reach the mileage limit, the maximum length of age may be allowed to extend, provided that it successfully passes all technical standards (Jiang and Yi, 1997; Ministry of Commerce of the PRC (MCC), 2000). Therefore, the survival rate follows an exponential function:

$$
S_{t}=S_{t-1} \cdot \mathrm{e}^{-0.02 t}
$$

where $S$ represents the share of the buses; $t$ represents the age of the buses.

\subsubsection{Direct Emission Factors}

There are no official emission factor data available in China. This study cites national vehicle emission standards data and some literature data. From China I emission standard to China $\mathrm{V}$, its automobile exhaust emission standards have been gradually benchmarking the standards of European. The target of China $\mathrm{V}$ emission standard is more inclined to the diesel vehicles with serious pollution, and the indicators of that have increased by a large margin. The particles concentration of China Vemission standard is even stricter by $82 \%$. Since 2017, China has focused on tightening the limits of nitrogen oxides and particulate matter emissions (Figure 2). The emission factors draw on the research results of previous scholars (Table 4). 


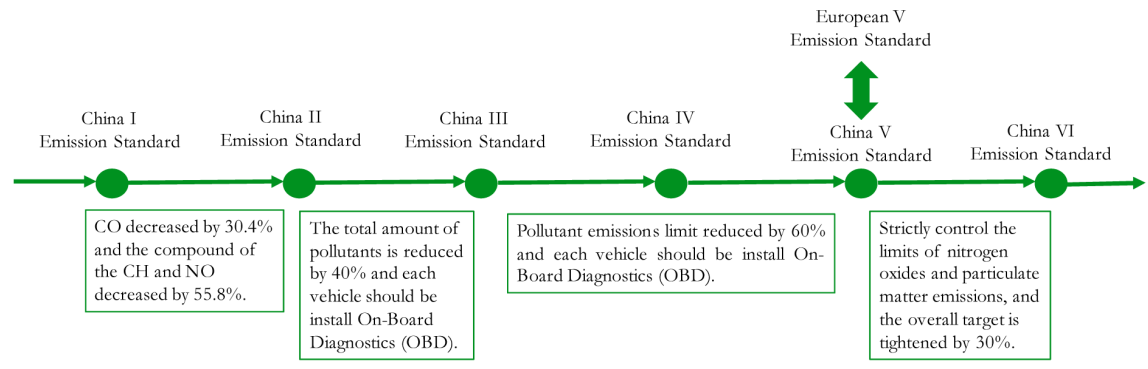

Figure 2. The evolution of China's emission standards.

Table 4. Direct emission factors for each bustype.

\begin{tabular}{|c|c|c|c|c|c|}
\hline Vehicle type & Source & $\begin{array}{c}\mathrm{CO}_{2} \\
(\mathrm{~g} / \mathrm{km})\end{array}$ & $\begin{array}{c}\mathrm{CO} \\
(\mathrm{g} / \mathrm{km})\end{array}$ & $\begin{array}{l}\mathrm{NO}_{\mathrm{x}} \\
(\mathrm{g} / \mathrm{km})\end{array}$ & $\begin{array}{l}\mathrm{PM}_{10} \\
(\mathrm{~g} / \mathrm{km})\end{array}$ \\
\hline Gasoline buses & Hu et al. (2006) & 1400 & 93.92 & 8.51 & 0.816 \\
\hline \multirow{6}{*}{ Diesel buses } & Hu et al. (2006) & 1171.32 & 7.2 & 21.33 & 0.126 \\
\hline & Euro I (2002) & 1125.9 & 3.3 & 11.6 & 0.6 \\
\hline & Euro II (2005) & 1082.5 & 3.0 & 12.4 & 0.3 \\
\hline & Euro IV (2010) & 1072.8 & 0.3 & 6.4 & 0.1 \\
\hline & Euro V (2016) & 1072.8 & 0.3 & 3.6 & 0.1 \\
\hline & Euro VI (2050) & 1072.8 & 0.3 & 0.7 & 0.1 \\
\hline \multirow{6}{*}{$\mathrm{CNG}$} & Hu et al. (2006) & 1072.4 & 79.96 & 8.79 & 0.071 \\
\hline & Euro I (2002) & 1530.6 & 8.4 & 16.5 & 0.1 \\
\hline & Euro II (2005) & 1420.3 & 2.7 & 15.0 & 0.1 \\
\hline & Euro IV (2010) & 1254.8 & 1.0 & 10.0 & 0.1 \\
\hline & Euro VI (2016) & 1254.8 & 1.0 & 10.0 & 0.1 \\
\hline & Euro VI (2050) & 1072.8 & 0.3 & 0.7 & 0.1 \\
\hline LPG & Hu et al. (2006) & 1254.4 & 87.13 & 6.93 & 0.083 \\
\hline $\begin{array}{c}\text { Bioethanol-gasoline } \\
\text { buses }\end{array}$ & Clairotte et al. (2013) & 1362.2 & 0.28 & 0.014 & 0.0005 \\
\hline Hybrid buses & Chen \& He (2013) & 77 & 95 & 0 & 21.6 \\
\hline Battery electric buses & - & - & - & - & - \\
\hline
\end{tabular}

Source: European emission standard is quoted from the earlier study (Cai \& Xie, 2010).

\subsubsection{Efficiency Parameters and Emission Factors of Life-Cycle Analysis}

To simplify, we refer to existing research parameters. Ignoring the impact of bus types and vehicle weight on energy consumption, the efficiency of diesel and gasoline buses from crude oil extraction to refined fuel is about $87 \%$, and from refinery transportation to the gas station consumes 5\%. Then the fuel efficiency of diesel and gasoline engine is about $35 \%$ and $20 \%$, respectively. Finally, the cycle energy efficiency of diesel and gasoline buses is $28.9 \%$ and $16.5 \%$, respectively (Figure 3). Diesel bus requires $45 \mathrm{~L}$ diesel fuel for $100 \mathrm{~km}$. The fuel consumption is the filling amount of the fuel station to the fuel tank. According to the diesel density $0.84 \mathrm{~g} / \mathrm{ml}$, diesel bus requires $55.1 \mathrm{~kg}$ standard coal for $100 \mathrm{~km}$, 


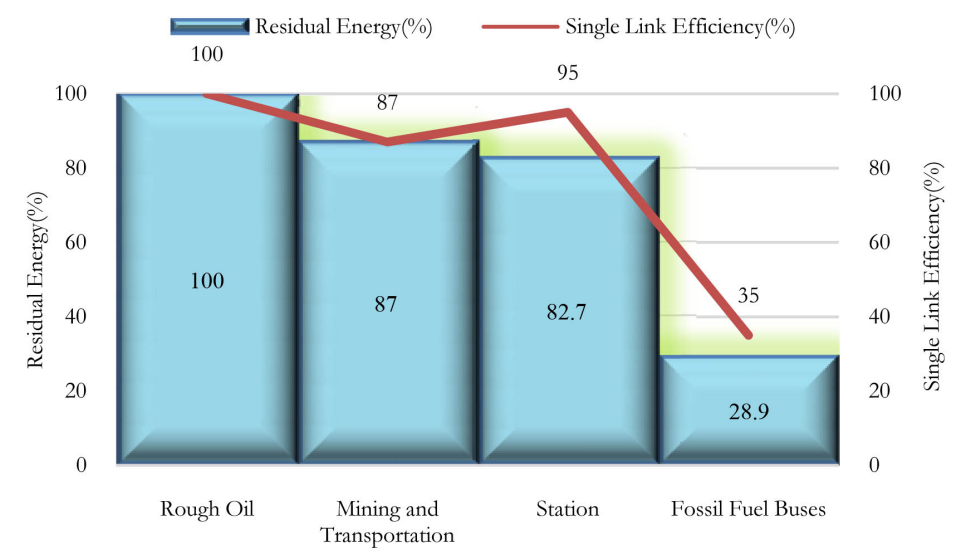

Figure 3. Energy efficiency of fossil fuel buses under Life Cycle Analysis (Sun et al., 2012).

which can be converted into $66.6 \mathrm{~kg}$ rough oil. Likewise, gasoline bus requires 55 $\mathrm{L}$ gasoline fuel for $100 \mathrm{~km}$. According to the gasoline density $0.72 \mathrm{~g} / \mathrm{ml}$, gasoline bus requires $58.3 \mathrm{~kg}$ standard coal for $100 \mathrm{~km}$, which can be converted into 70.5 kg rough oil (Kong et al., 2012).

In the China's power generation industry, electricity generating from coal-fired units account for about $76 \%$ of total generation, that is, electricity mainly comes from coal. According to the statistics of the China Electricity Council, in 2010, the net coal consumption rate of thermal power plants above $6000 \mathrm{~kW}$ is 333 $\mathrm{g} /(\mathrm{kWh})$. The power supply efficiency is about $36.9 \%$, and the national average power line loss rate was $6.5 \%$. Assume that the efficiency of coal mining, transportation, washing and other processes before coal-fired power generation is $90 \%$, and we find that the full-cycle energy efficiency of electric buses under coal-fired power generation is about $25.2 \%$ (Figure 3 ). The electric bus requires $150 \mathrm{kWh}$ electricity for $100 \mathrm{~km}$. This consumption is the amount of electricity charged by the power grid to the battery. Of this, the coal-fired unit supplies 114 $\mathrm{kW}$ helectricity, and the thermal power plants consume $40.4 \mathrm{~kg}$ standard coal, which can be converted into $44.9 \mathrm{~kg}$ rough coal (Figure 4).

According to China Statistical Yearbook 2011 and China Energy Statistical Yearbook 2011, one-ton standard coal for power generation will equally discharge $1.74 \mathrm{~kg}$ particulate matter $\mathrm{PM}$ and $6.6 \mathrm{~kg}$ nitrogen oxides $\mathrm{NO}_{\mathrm{x}}$ in 2010 . If one electric bus requires $150 \mathrm{kWh}$ electricity for $100 \mathrm{~km}$, it will discharge $70.5 \mathrm{~g}$ pollutant particles PM and $265.5 \mathrm{~g}$ nitrogen oxides $\mathrm{NO}_{\mathrm{x}}$ (as shown in Table 5).

\subsubsection{Exposure-Response Coefficients}

Existing epidemiological research of the exposure-response function can quantify the physical volume of residents' health hazards at certain air pollutant levels. To simplicity, this study treats China as a whole without any distinction between geography condition and other details. Considering the availability of exposure-response coefficients, this study selected health outcome closely related to bus pollutant emissions includes respiratory mortality, cardiovascular mortality, respiratory hospitalizations, cardiovascular hospitalization, asthma visit and acute bronchitis visit (Table 6). 


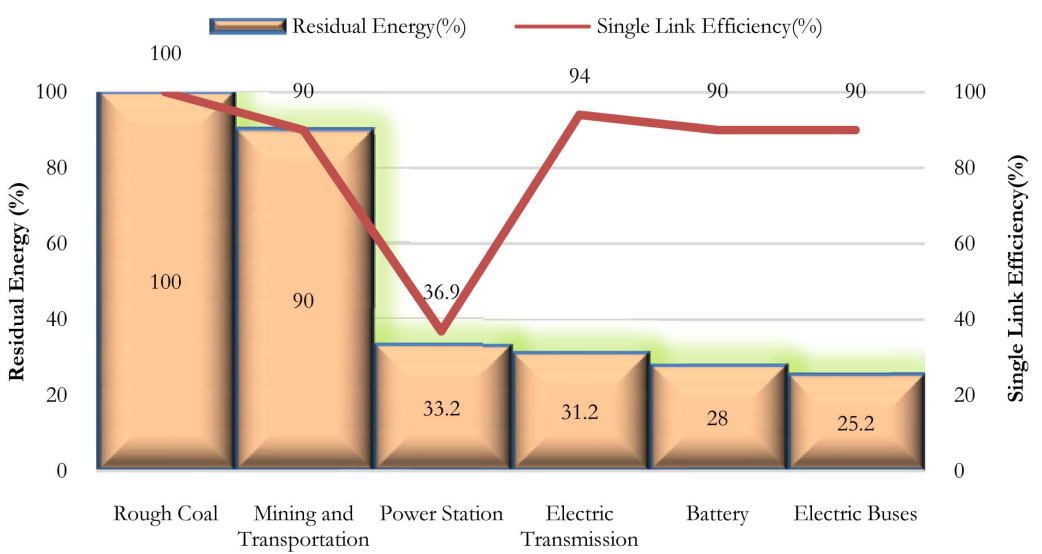

Figure 4. Energy efficiency of electric buses under life cycle analysis (Kong et al., 2012).

Table 5. Energy consumption and pollutant emissions (100 km).

\begin{tabular}{|c|c|c|c|c|c|c|}
\hline & $\begin{array}{l}\text { Fuel consumption } \\
\text { (Physical volume) }^{1}\end{array}$ & $\begin{array}{c}\text { Material consumption } \\
\text { (Standard coal) }(\mathrm{kg})\end{array}$ & $\begin{array}{l}\mathrm{CO}_{2} \\
(\mathrm{~kg})\end{array}$ & $\begin{array}{l}\mathrm{CO} \\
(\mathrm{kg})\end{array}$ & $\begin{array}{l}\mathrm{NO}_{x} \\
(\mathrm{~kg})\end{array}$ & $\begin{array}{l}\text { PM } \\
(\mathrm{kg})\end{array}$ \\
\hline Gasoline buses & $55 \mathrm{~L}$ gasoline & $70.5 \mathrm{~kg}$ rough oil & 134.57 & 1.112 & 1.497 & 0.794 \\
\hline Diesel buses & $45 \mathrm{~L}$ diesel & $66.6 \mathrm{~kg}$ rough oil & 110.10 & 0.910 & 1.225 & 0.065 \\
\hline Hybrid buses & $\begin{array}{c}38.5 \mathrm{~L} \text { gasoline } \\
+45 \mathrm{kWh} \text { electricity }\end{array}$ & $\begin{array}{c}46.6 \mathrm{~kg} \text { rough oil } \\
+13.5 \mathrm{~kg} \text { rough coal }\end{array}$ & 109.89 & 0.637 & 0.937 & 0.069 \\
\hline $\begin{array}{c}\text { Battery } \\
\text { electric buses }\end{array}$ & $150 \mathrm{kWh}$ electricity & $44.9 \mathrm{~kg}$ rough coal & 109.28 & - & 0.265 & 0.071 \\
\hline
\end{tabular}

Source: the data of Fuel consumption and pollutant emissions is quoted from the earlier study (Ou et al., 2008; Kong et al., 2012).

Table 6. Exposure-response coefficients of health outcome.

\begin{tabular}{cccc}
\hline Health outcome & Pollutants & Exposure-response coefficient & References \\
\hline Respiratory mortality & $\mathrm{NO}_{\mathrm{x}}$ & 1.62 & Shang et al. (2013) \\
& $\mathrm{PM}_{10}$ & 0.32 & Shang et al. (2013) \\
Cardiovascular mortality & $\mathrm{NO}_{\mathrm{x}}$ & 1.46 & Shang et al. (2013) \\
& $\mathrm{PM}_{10}$ & 0.43 & Shang et al. (2013) \\
Respiratory hospitalizations & $\mathrm{NO}_{\mathrm{x}}$ & 2.57 & Zhang et al. (2015) \\
& $\mathrm{PM}_{10}$ & 1.72 & Zhang et al. (2015) \\
Cardiovascular hospitalization & $\mathrm{NO}_{\mathrm{x}}$ & 1.18 & Zhang et al. (2015) \\
& $\mathrm{PM}_{10}$ & 1.39 & Zhang et al. (2015) \\
Asthma visit & $\mathrm{NO}_{\mathrm{x}}$ & 1.46 & Halonen et al. (2008) \\
& $\mathrm{PM}_{10}$ & 1.50 & Guo et al. (2018) \\
& $\mathrm{NO}_{\mathrm{x}}$ & 1.19 & Guo et al. (2018) \\
Acute bronchitis visit & $\mathrm{PM}_{10}$ & 0.31 & Guo et al. (2018) \\
\hline
\end{tabular}

Exposure-response coefficients indicate the percentage of health outcome increases when pollutant concentration increases $10 \mu \mathrm{g} / \mathrm{m}^{3}$. 


\subsubsection{The Economic Losses of Residents}

This study uses the VSL, WTP and COI as assessment methods to convert the physical volume of residents' health hazards caused by bus pollutants emissions into economic losses (as shown in Table 7).

\section{Scenario Design}

In 2015, the National Development and Reform Commission ("NDRC") has promulgated the Opinions on Giving Better Play to the Role of Transportation in Supporting and Leading Economic and Social Development at Present, which is called "China's Transportation 2050". The Opinions points out that it is necessary to vigorously develop various forms of large-capacity public transportation, and build green transport system based on public transportation. The important issues of the Opinions are encouraging the application of new energy vehicles and speeding up the elimination of old vehicles. Therefore, this study will regard the year 2050 as the future scenario period.

In the first step, the business as usual (BAU) assumes that government to do nothing to influence the long-term development trend of public transportation. As China has implemented the Euro VI emission standard since 2018, we set that the current emission standard is Euro VI and the sales growth rate of buses is 3.05\% according to the growth rate in 2010-2014.

In the second step, we make policy interventions. The development trend of public transportation mainly needs to meet the following two needs:

1) To meet the urban modernization construction, that is, to meet the goal of urban public transportation construction. In 2014, China had a population of 1.37 billion, which will reach 1.44 billion in 2030 and fall to 1.36 billion in 2050 according to The United Nations Outlook. The state regulation is that bus equipped with 7 and 12 sets per 10,000 people in small and medium-sized cities and the national civilized Class A cities, which is estimated 0.955 million and 1.673 million buses, respectively.

2) To meet the alternative requirements of public transportation, that is, to meet the goal of prioritizing public transportation. In 2013, the State Council of

Table 7. The economic losses of health outcome (RMB).

\begin{tabular}{cccc}
\hline Health outcome & Methods & Unit cost & References \\
\hline $\begin{array}{c}\text { Respiratory mortality } \\
\text { Cardiovascular mortality }\end{array}$ & VSL & $933,841.2$ & Xie (2011) \\
VSL & $933,841.2$ & Xie (2011) \\
Respiratory hospitalizations & COI & 5080.8 & $\begin{array}{c}\text { China Health and Family Planning } \\
\text { Statistical Yearbook 2013 } \\
\text { Cardiovascular hospitalization }\end{array}$ \\
A & COI & 7147.9 & $\begin{array}{c}\text { China Health and Family Planning } \\
\text { Statistical Yearbook 2013 }\end{array}$ \\
Acute bronchitis visit & WTP & 78.18 & Kan \& Chen (2004) \\
\hline
\end{tabular}

The parameters of asthma visit and acute bronchitis visit are based on the ratio of per capita disposable income of the specific city and nation in basic year. 
China deployed ten measures to control air pollution. The measures explicitly proposed the priority of public transportation development to ensure that the concentration of atmospheric pollutants in key industries fell by $30 \%$ by the end of 2017. We draw on the setting of existing study. According to BAU of the existing study, the total annual mileage traveled by buses is 27.42 billion kilometers, and the annual mileage of each bus is 35,000 kilometers, which is estimated 783,400 buses in 2050 . In the scenario three, it assumes that $20 \%$ of the increased mileage of private and commercial vehicles will be transferred to buses. It means that the total annual mileage traveled by buses is 62.65 billion kilometers, which is estimated 1.79 million buses in 2050. In the scenario four, it assumes that $30 \%$ of the increased mileage of private and commercial vehicles will be transferred to buses. It means that the total annual mileage traveled by buses is 80.27 billion kilometers, which is estimated 2.39 million buses in 2050 (He \& Qiu, 2016).

In the third step, we set up the scenario of promoting new energy buses under different growth rates of public transportation. In 2018, the State Council of China issued the Development Plan of Modern Comprehensive Transportation System (the 13th Five-Year Plan), which mentioned that the convenient, efficient, and green transportation system will be built in 2020 and some regions will take the lead in achieving modernization of transportation. Therefore, we set that the sales rate of new energy buses will reach $80 \%$ by 2020 , and new energy buses will be fully promoted by 2030 . Within the new energy buses, the sales rate of battery electric buses will reach $60 \%$ and $80 \%$ by 2020 and 2030, respectively. In 2050, it fully promoted battery electric buses (Table 8).

Table 8. Scenario and definition.

\begin{tabular}{|c|c|c|c|}
\hline Hypothesis & Scenario & Abbreviation & Definition \\
\hline $\begin{array}{l}\text { Baseline } \\
\text { reference }\end{array}$ & Business As Usual & BAU & $\begin{array}{l}\text { The sales growth rate is } 3.05 \% \text {; } \\
\text { Euro VI emission standard }\end{array}$ \\
\hline $\begin{array}{l}\text { Meet the urban } \\
\text { modernization } \\
\text { construction }\end{array}$ & $\begin{array}{l}\text { Achieve the standard of he } \\
\text { national civilized Class A cities }\end{array}$ & CCS & $\begin{array}{l}\text { The sales growth rate is } 5.55 \% \text {; } \\
\text { Euro VI emission standard }\end{array}$ \\
\hline Meet the alternative & $\begin{array}{l}20 \% \text { of the increased mileage of } \\
\text { private and commercial } \\
\text { vehicles will be transferred to buses }\end{array}$ & IBS20\% & $\begin{array}{l}\text { The sales growth rate is } 5.86 \% \text {; } \\
\text { Euro VI emission standard }\end{array}$ \\
\hline public transportation & $\begin{array}{l}30 \% \text { of the increased mileage of } \\
\text { private and commercial vehicles } \\
\text { will be transferred to buses }\end{array}$ & IBS30\% & $\begin{array}{l}\text { The sales growth rate is } 6.5 \% \text {; } \\
\text { Euro VI emission standard }\end{array}$ \\
\hline $\begin{array}{c}\text { Promoting } \\
\text { new energy buses }\end{array}$ & All of Above & $\begin{array}{l}\text { INEV } \\
\text { INEVccs } \\
\text { INEV20\% } \\
\text { INEV30\% }\end{array}$ & $\begin{array}{l}\text { The sales rate of new energy buses } \\
\text { will reach } 80 \% \text { and } 100 \% \\
\text { by } 2020 \text { and } 2030 \text {, respectively; } \\
\text { Within the new energy buses, } \\
\text { the sales rate of battery electric buses } \\
\text { will reach } 60 \% \text { and } 80 \% \\
\text { by } 2020 \text { and } 2030 \text {, respectively; } \\
\text { In } 2050 \text {, it fully promoted } \\
\text { battery electric buses }\end{array}$ \\
\hline
\end{tabular}




\section{Results}

\subsection{Buses Inventory Estimation}

With the help of LEAP model, we estimate the inventory of buses using different fuel types (2015-2050) under different scenarios.

The results of the simulation show that: 1) With the sales rate set by the scenario, whether it meets which hypothesis, the total amount will decrease first and then slowly rise from 2020 to 2030 (As shown in Figure 5 and Figure 6). That is, at the early stage, the vehicle growth rate is less than the elimination rate, which indicates that this period is the transition period of update from the traditional energy buses to the energy-saving buses or the new energy buses. 2) Comparing the growth trends of different buses types respectively, we will find that traditional energy buses will gradually withdraw from the market, and the growth rate of energy-saving buses will slow down in the later period. Under the scenario of promoting new energy buses, the inventory of energy-saving buses has dropped sharply (As shown in Figure 7). Promoting new energy buses has replaced the growth of energy-saving buses to a certain extent.

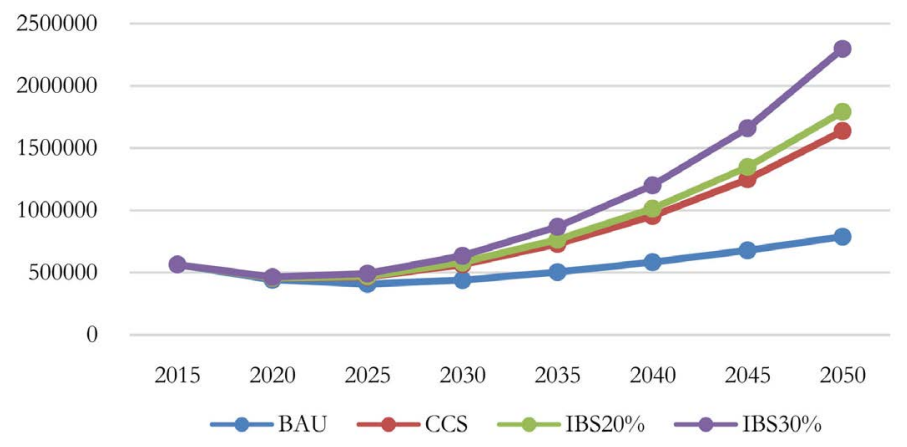

Figure 5. Estimating trends of inventory under different scenarios.

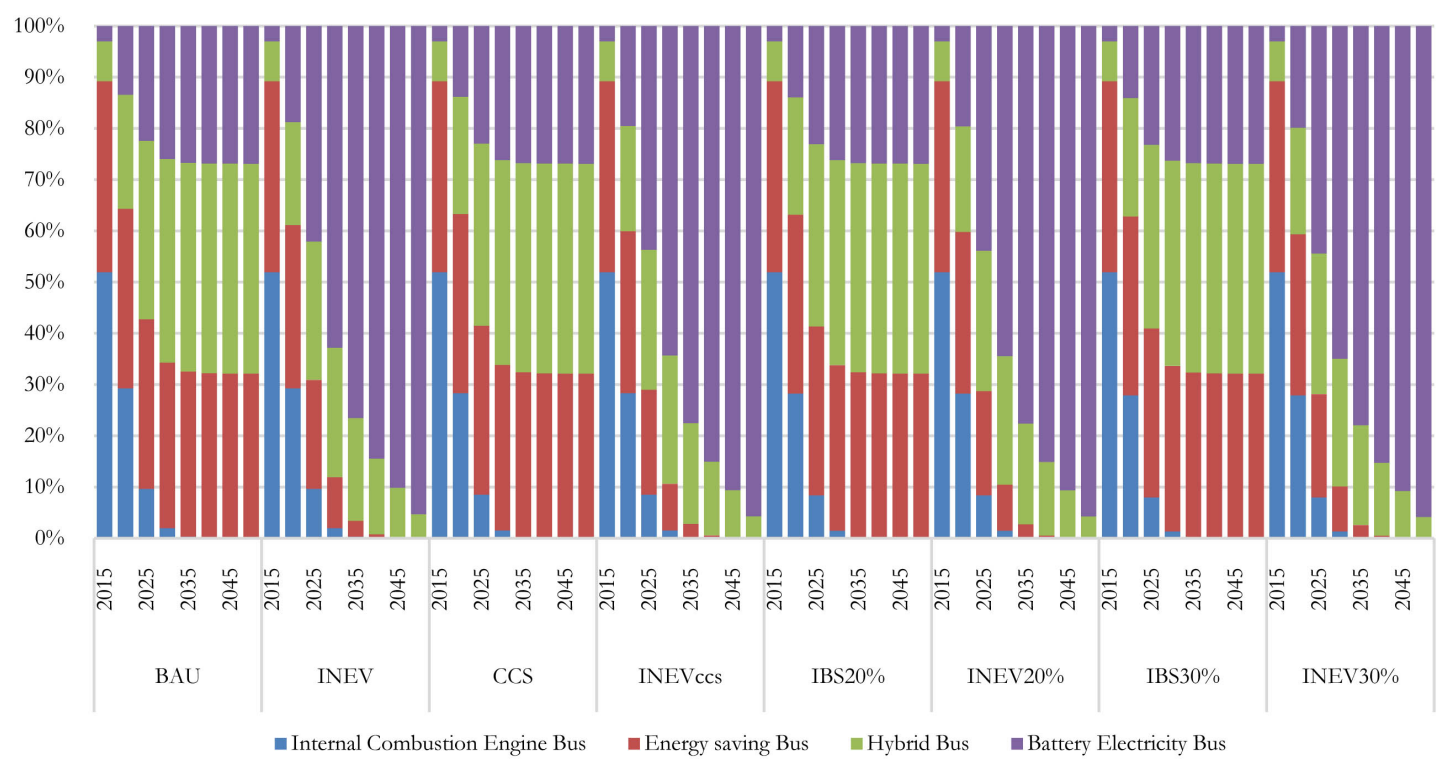

Figure 6. Estimating trends of inventory under different scenarios (Area chart). 


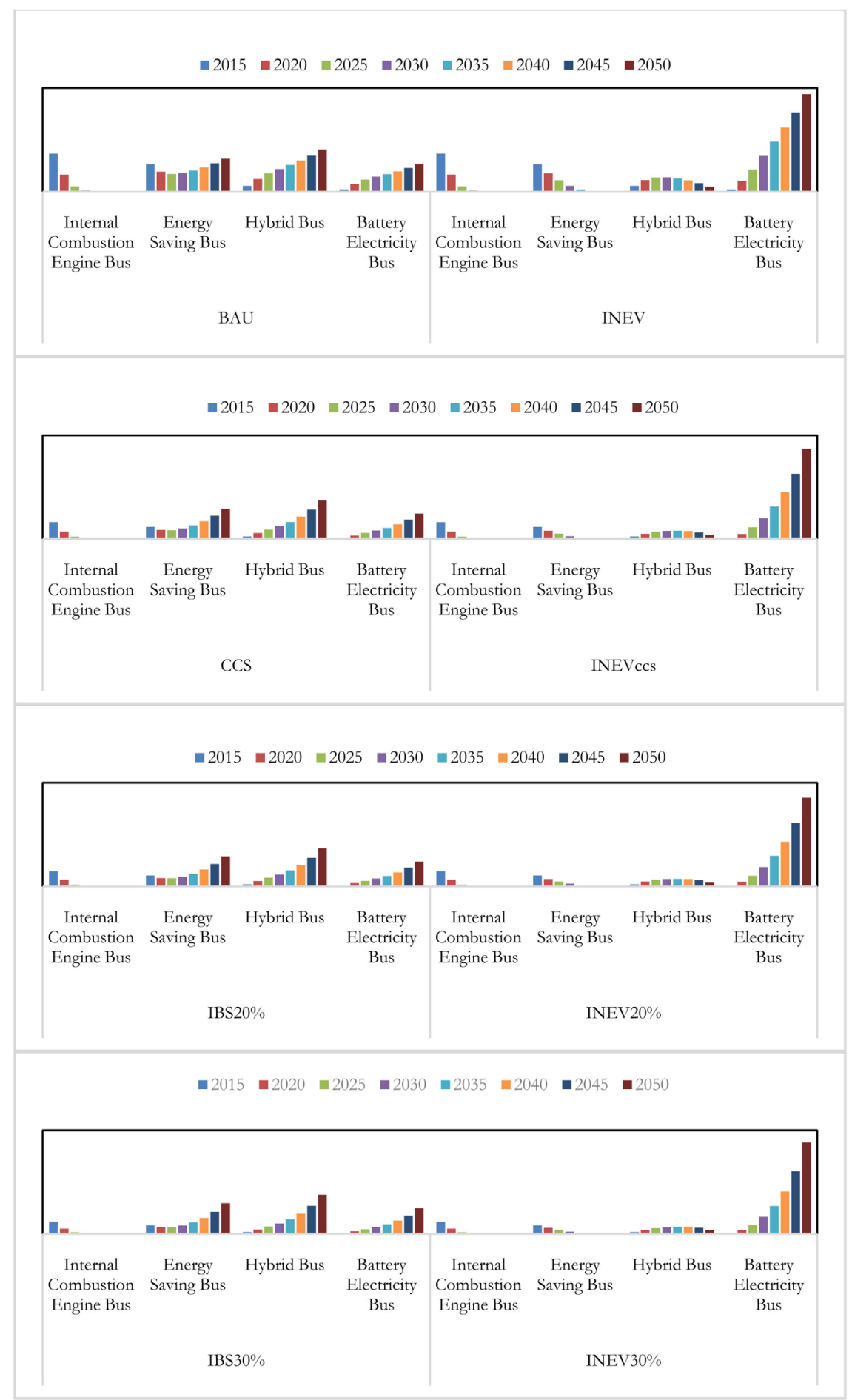

Figure 7. Estimating trends of inventory using different fuel under different scenarios.

\subsection{The Emission Reduction of Promoting New Energy Buses}

The estimating trends of greenhouse gases and pollutants emission under different scenarios show that: 1) In the setting scenario CCS, IBS 20\% and IBS 30\%, greenhouse gas $\mathrm{CO}_{2}$, atmospheric pollutant $\mathrm{CO}, \mathrm{NO}_{\mathrm{x}}$ and particulate matter PM10 emitted by buses exhaust have been a year-on-year rise. 2) Comparing the 
setting scenarios BAU and INEV, CCS and INEVccs, IBS20\% and INEV20\%, IBS30\% and INEV30\% respectively, we will find that promoting new energy buses have a significant effect of pollutant reduction, but under the case of life cycle analysis, the greenhouse gas is surging rather than falling (As shown in Figure 8). The main reason for the negative effect of greenhouse gas reduction is that China's current coal-fired power generation accounts for a large proportion. The greenhouse gas reduction of new energy buses in the terminal are not enough to offset the greenhouse gas generated by power generation and transportation.

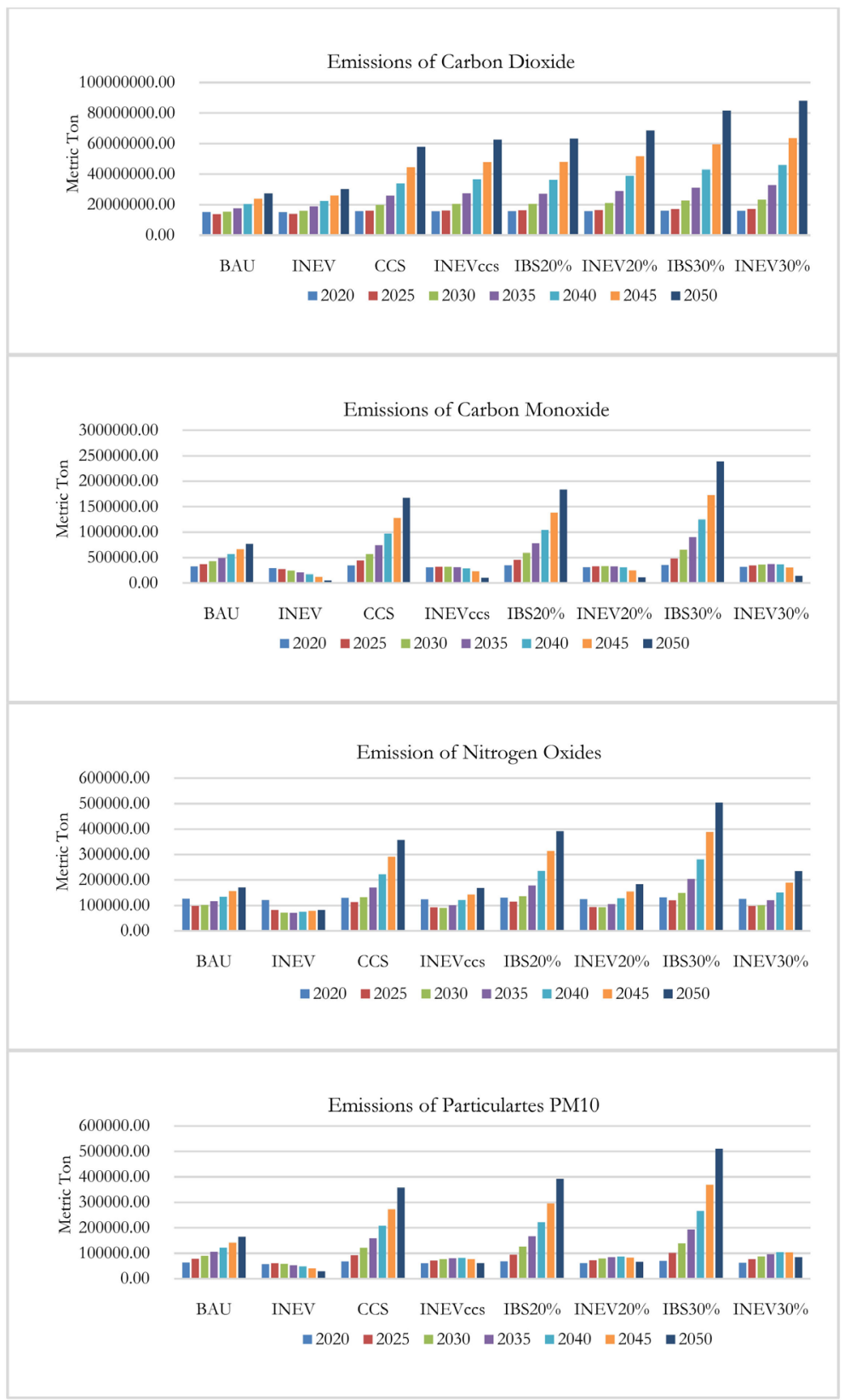

Figure 8. Estimating trends of emission of greenhouse gases and pollutants under different scenarios. 
The test results of emission reduction under different scenarios show that the greenhouse gas reduction effect of promoting new energy buses is negative under the condition of life cycle analysis, but the efficiency of atmospheric pollutants reduction is remarkable. In 2030, the emission reduction ratios of atmospheric pollutants $\mathrm{CO}, \mathrm{NO}_{\mathrm{x}}$ and particulate matter $\mathrm{PM}_{10}$ are $40 \%, 30 \%$ and $35 \%$ respectively; in 2050, the atmospheric pollutant $\mathrm{CO}$ emission reduction ratio is over $90 \%$. The emission reduction efficiency of $\mathrm{NO}_{\mathrm{x}}$ is about $52 \%$, and $\mathrm{PM}_{10}$ is about $83 \%$ (As shown in Table 9).

\subsection{The Estimating Results of Residents' Health Losses}

The United Nations estimates that China's population will reach 1.3645 billion in 2050. We assume that one-third of the population will be exposed to harsh conditions by 2050. At the same time, in order to do a quantitative study of economic losses caused by pollutants, we will set two scenarios. One is the background concentration, that is, there is no natural state of pollutants caused by human activities. We set that the annual average concentrations of $\mathrm{NO}_{\mathrm{x}}$ and PM10 are $21 \mu \mathrm{g} / \mathrm{m}^{3}$ (Chen \& He, 2013) and $10 \mu \mathrm{g} / \mathrm{m}^{3}$ (Wu et al., 2010) respectively. The other is the air pollutant concentration value of the baseline scenario. We set that the annual average concentration of $\mathrm{NO}_{\mathrm{x}}$ and $\mathrm{PM}_{10}$ are $37.25 \mu \mathrm{g} / \mathrm{m}^{3}$ and $28.9 \mu \mathrm{g} / \mathrm{m}^{3}$ (iFinD database) in 2020 respectively. According to the model described in 3.1.2, we calculate the air pollutant concentration values for 2030 and 2050 (as shown in Table 10).

Table 9. The emission reduction of promoting new energy buses under different scenarios (\%).

\begin{tabular}{|c|c|c|c|c|c|c|c|c|}
\hline Pollutant & Scenario & 2020 & 2025 & 2030 & 2035 & 2040 & 2045 & 2050 \\
\hline \multirow{4}{*}{ Carbon Dioxide } & BAU-INEV & 0.36 & -0.76 & -3.61 & -6.96 & -8.83 & -9.16 & -9.81 \\
\hline & CCS-INEVccs & 0.39 & -0.60 & -3.12 & -6.07 & -7.61 & -7.80 & -8.47 \\
\hline & IBS20\%-INEV20\% & 0.39 & -0.58 & -3.06 & -5.96 & -7.47 & -7.64 & -8.31 \\
\hline & IBS30\%-INEV30\% & 0.41 & -0.53 & -2.89 & -5.68 & -7.08 & -7.22 & -7.90 \\
\hline \multirow{4}{*}{ Carbon Monoxide } & BAU-INEV & 10.52 & 26.56 & 42.98 & 57.70 & 69.90 & 81.67 & 93.39 \\
\hline & CCS-INEV ccs & 10.89 & 27.13 & 43.57 & 58.17 & 70.30 & 82.05 & 93.77 \\
\hline & IBS20\%-INEV20\% & 10.94 & 27.19 & 43.63 & 58.22 & 70.35 & 82.10 & 93.82 \\
\hline & IBS30\%-INEV30\% & 11.06 & 27.38 & 43.82 & 58.37 & 70.47 & 82.22 & 93.94 \\
\hline \multirow{4}{*}{ Nitrogen Oxides } & BAU-INEV & 4.31 & 16.77 & 30.46 & 39.24 & 44.59 & 49.66 & 52.08 \\
\hline & CCS-INEVccs & 4.60 & 17.80 & 31.78 & 40.46 & 45.73 & 50.74 & 52.88 \\
\hline & IBS20\%-INEV20\% & 4.64 & 17.93 & 31.94 & 40.60 & 45.86 & 50.86 & 52.96 \\
\hline & IBS30\%-INEV30\% & 10.94 & 27.19 & 43.63 & 58.22 & 70.35 & 82.10 & 93.82 \\
\hline \multirow{4}{*}{ Particulates PM10 } & BAU-INEV & 10.27 & 23.18 & 36.22 & 48.82 & 60.02 & 71.15 & 82.32 \\
\hline & CCS-INEVccs & 10.56 & 23.61 & 36.78 & 49.44 & 60.69 & 71.88 & 83.09 \\
\hline & IBS20\%-INEV20\% & 10.60 & 23.66 & 36.85 & 49.51 & 60.77 & 71.96 & 83.18 \\
\hline & IBS30\%-INEV30\% & 10.70 & 23.80 & 37.03 & 49.70 & 60.98 & 72.18 & 83.41 \\
\hline
\end{tabular}


Table 10. Air pollutant concentration in the future scenarios.

\begin{tabular}{cccccccccc}
\hline Year & $\begin{array}{c}\text { Pollutant } \\
\text { concentration }\end{array}$ & BAU & CCS & IBS20\% & IBS30\% & INEV & INEVccs & INEV20\% & INEV30\% \\
\hline \multirow{2}{*}{2030} & $\mathrm{NO}_{\mathrm{x}}$ & 32.02 & 37.75 & 38.56 & 40.92 & 26.01 & 29.84 & 30.38 & 31.96 \\
& $\mathrm{PM}_{10}$ & 32.35 & 35.25 & 35.65 & 36.83 & 29.07 & 31.07 & 31.35 & 32.16 \\
\multirow{2}{*}{2050} & $\mathrm{NO}_{\mathrm{x}}$ & 46.88 & 85.01 & 91.85 & 114.17 & 28.47 & 47.06 & 50.37 & 61.18 \\
& $\mathrm{PM}_{10}$ & 41.67 & 62.94 & 66.73 & 79.09 & 25.07 & 28.93 & 29.61 & 31.79 \\
\hline
\end{tabular}

The results of the economic losses of residents' health caused by buses exhaust show that: 1) Under the baseline scenario BAU, the economic losses of residents' health caused by atmospheric pollutants $\mathrm{NO}_{\mathrm{x}}$ and $\mathrm{PM}_{10}$ emitted by bus exhausts in China in 2030 and 2050 are 859.062 billion RMB and 1200.276 billion RMB, which are equivalent to $1.04 \%$ and $1.45 \%$ of the national GDP in 2017 , respectively. Among them, the economic losses caused by respiratory diseases are the largest, which are accounting for $59.46 \%$ of total value. The second one is cardiovascular disease. 2) In the setting scenario CCS, IBS $20 \%$ and IBS $30 \%$, the economic losses of residents' health caused by exhaust pollutants $\mathrm{NO}_{\mathrm{x}}$ and $\mathrm{PM}_{10}$ are increasing whether in 2030 or 2050 . Without planning and intervention, the economic losses of residents' health caused by the bus industry in adapting to the urban modernization construction and the replacement demand of the public transportation system are gradually increasing. It means that while the public transport system is slowing down the negative externalities brought about by private transportation, there is also room for optimization. 3) Comparing the setting scenario BAU and INEV, CCS and INEVccs, IBS 20\% and INEV20\%, IBS $30 \%$ and INEV $30 \%$ respectively, the results show that promoting new energy buses vigorously can make the economic losses of residents' health reduced significantly. Especially in the future scenario 2050, when the traditional energy buses are completely replaced by the new energy buses, the economic losses of residents' health will be reduced by $39.31 \%$ to $50.31 \%$, and the effect on the residents' welfare is considerable (as shown in Table 11).

\section{Discussion}

\subsection{Summary}

We set up four scenarios which based on two basic assumptions of meeting urban modernization and the requirements of public transportation replacement to promote the environmental impact and economic effects of new energy buses from the whole life cycle analysis. Then, we set the further scenarios that comprehensively promote new energy in the basic situation to calculate the impact on residents' health benefits and the economic benefits of carbon and pollutant reduction in different situations.

We find that the emissions of atmospheric pollutants such as carbon monoxide $\mathrm{CO}$, nitrogen oxides $\mathrm{NO}_{\mathrm{x}}$ and particulate matter PM will be significantly reduced after the promoting new energy buses comprehensively, which will help 
Table 11. Economic losses caused by air pollutant under different scenarios.

\begin{tabular}{ccccc}
\hline Scenario & $\begin{array}{c}2030 \\
(\text { Billion RMB })\end{array}$ & $\begin{array}{c}2050 \\
(\text { Billion RMB })\end{array}$ & $\begin{array}{c}\text { Proportion of } \\
\text { GDP in 2017 (2030) }\end{array}$ & $\begin{array}{c}\text { Proportion of } \\
\text { GDP in 2017 (2050) }\end{array}$ \\
\hline BAU & 859.0692 & 1200.2716 & $1.04 \%$ & $1.45 \%$ \\
INEV & 725.7780 & 726.5445 & $0.88 \%$ & $0.88 \%$ \\
CCS & 983.5360 & 2049.4718 & $1.19 \%$ & $2.48 \%$ \\
INEVccs & 809.8200 & 1074.9299 & $0.98 \%$ & $1.30 \%$ \\
IBS20\% & 1001.0604 & 2201.5955 & $1.21 \%$ & $2.66 \%$ \\
INEV20\% & 821.6079 & 1136.9945 & $0.99 \%$ & $1.37 \%$ \\
IBS30\% & 1052.3492 & 2697.7591 & $1.27 \%$ & $3.26 \%$ \\
INEV30\% & 856.0808 & 1338.9348 & $1.04 \%$ & $1.62 \%$ \\
\hline
\end{tabular}

China achieve the goal of reducing pollution, improving urban air quality and reducing expenditure of residents' disease effectively, thereby improving residents' welfare. However, because coal-fired power generation still accounts for a dominant position in China, the emissions of greenhouse gas $\mathrm{CO}_{2}$ are surging rather than falling after promoting new energy buses comprehensively. The targets of greenhouse gas reduction cannot be fully realized. The economic losses of residents' health after promoting new energy buses comprehensively will be reduced by $39.31 \%$ to $50.31 \%$, which indicates that the effect on the residents' welfare is considerable.

In summary, new energy buses have obvious advantages in energy conservation and pollution mitigation. In the future, it will bring good environmental impact and huge economic benefits to China in terms of environmental protection and energy conservation with the premise of ensuring grid security, the improvement of China's energy structure, breakthroughs in battery technology and the full deployment of infrastructure.

\subsection{Policy Suggestion}

The first suggestion is to increase the technology of new energy buses and optimize the policy environment of promoting new energy buses. According to the results of future scenario, while under the full life cycle assessment method, the promoting new energy buses can achieve the goal of reducing polluting gas emissions, thereby reducing the health economic losses and improving the welfare of residents. Therefore, promoting new energy buses is one of the important measures to deal with the energy crisis and environmental pollution. At present, the commercialization process of new energy buses is still in its infancy. In the future, it is necessary to increase the research of batteries and the improvement of endurance. At the same time, it is important to optimize the policy environment for promoting new energy buses. We must do a good job in the comprehensive construction of infrastructure such as giving priority to the land for charging stations or incorporating charging pile facilities into the overall urban planning. 
The second is suggestion to optimize the power generation structure and improve the electricity efficiency of new energy buses. Comparing the efficiency of driving process and the whole life cycle assessment method, it can be seen that a large amount of polluting gasemits during the process of raw material mining, producing and transporting. New energy buses are the general trend of road transportation industry in the next 50 years. To order to achieve energy conservation and emission reduction targets, it is necessary to speed up the technical transformation of coal-fired power plants and increase the proportion of clean energy power generation.

\section{Conflicts of Interest}

The author declares no conflicts of interest regarding the publication of this paper.

\section{References}

Bose, R. K., \& Srinivasachary, V. (1997). Policies to Reduce Energy Use and Environmental Emissions in the Transport Sector: A Case of Delhi City. Energy Policy, 25, 1137-1150. https://doi.org/10.1016/S0301-4215(97)00106-7

Brady, J., \& O’Mahony, M. (2011). Travel to Work in Dublin. The Potential Impacts of Electric Vehicles on Climate Change and Urban Air Quality. Transportation Research Part D: Transport \& Environment, 16, 188-193.

Cai, H., \& Xie, S. D. (2010). Determination of Emission Factors from Motor Vehicles under Different Emission Standards in China. Acta Scientiarum Naturalium Universitatis Pekinensis, 46, 319-326.

Che, W., Zheng, J., Wang, S. et al. (2011). Assessment of Motor Vehicle Emission Control Policies Using Model-3/CMAQ Model for the Pearl River Delta Region, China. Atmospheric Environment, 45, 1740-1751. https://doi.org/10.1016/j.atmosenv.2010.12.050

Chen, R. J. (2013). The Health Effects of Complex Air Pollution in 17 Chinese Cites. Shanghai: Fudan University. (In Chinese)

Chen, S.-M., \& He, L.-Y. (2014). Welfare Loss of China's Air Pollution: How to Make Personal Vehicle Transportation Policy. China Economic Review, 31, 106-118. https://doi.org/10.1016/j.chieco.2014.08.009

Clairotte, M., Adam, T. W., Zardini, A. A., Manfredi, U., Martini, G., Krasenbrink, A., Vicet, A., Tournié, E., \& Astorga, C. (2013). Effects of Low Temperature on the Cold Start Gaseous Emissions from Light Duty Vehicles Fuelled by Ethanol-Blended Gasoline. Applied Energy, 102, 44-54. https://doi.org/10.1016/j.apenergy.2012.08.010

Fan, S. B., Zhang, D. X., Tian, L. D. et al. (2016). Emission Inventory and Spatial Distribution of Road Fugitive Dust $\mathrm{PM}_{2.5}$ in Beijing. Research of Environmental Sciences, 29, 20-28. (In Chinese)

Guo, H., Huang, S., \& Chen, M. (2018). Air Pollutants and Asthma Patient Visits: Indication of Source Influence. Science of the Total Environment, 625, 355-362. https://doi.org/10.1016/j.scitotenv.2017.12.298

Guo, X. R., Cheng, S. Y., Chen, D. S. et al. (2010). Estimation of Economic Costs of Particulate Air Pollution from Road Transport in China. Atmospheric Environment, 44, 3369-3377. https://doi.org/10.1016/j.atmosenv.2010.06.018

Halonen, J. I., Lanki, T., Yli-Tuomi, T. et al. (2008). Urban Air Pollution, and Asthma and 
COPD Hospital Emergency Room Visits. Thorax, 63, 635-641.

https://doi.org/10.1136/thx.2007.091371

He, J. C. (2015). Estimation of Air Pollutant Emission from Vehicles in Beijing-Harbin Highway. Ecological Science, 34, 154-157. (In Chinese)

He, L.-Y., \& Chen, Y. (2013). Thou Shalt Drive Electric and Hybrid Vehicles: Scenario Analysis on Energy Saving and Emission Mitigation for Road Transportation Sector in China. Transport Policy, 25, 30-40. https://doi.org/10.1016/j.tranpol.2012.11.006

He, L.-Y., \& Qiu, L.-Y. (2016). Transport Demand, Harmful Emissions, Environment and Health Co-Benefits in China. Energy Policy, 97, 267-275. https://doi.org/10.1016/j.enpol.2016.07.037

Hu, J., Hao, J., \& Fu, L. (2006). Impact of Gas Powered Vehicles on Vehicular Emissions in Beijing. Journal of Tsinghua University, 46, 350-354. (In Chinese)

Kan, H., \& Chen, B. (2004). Particulate Air Pollution in Urban Areas of Shanghai, China: Health-Based Economic Assessment. Science of the Total Environment, 322, 71-79. https://doi.org/10.1016/j.scitotenv.2003.09.010

Kong, W. Z., Li, Q. H., \& Wang, X. L. (2012). Analysis on Energy Saving and Emission Reduction of Electric Vehicles Based upon Life-Cycle Energy Efficiency. Electric Power, 45, 64-67. (In Chinese)

Liu, X. M., Liu, L. Q., Xu, M. M. et al. (2014). Relationships between Ambient Nitrogen Dioxide and Population Mortality of Respiratory Disease in Beijing. Journal of Environment and Health, 31, 565-568. (In Chinese)

Ou, X. M., Qi, T. Y., \& Zhang, X. L. (2009). Preliminary Analysis of Energy-Saving and Emission-Reduction Effect from New Energy Vehicle Financial Subsidy by Case of HEV Bus. Innovation and Reform of Environmental Financing Policies in China. (In Chinese)

Ou, X. M., Zhang, X. L., \& Chang, S. Y. (2008). Contrastive Analysis on the Energy Consumption and the Lifecycle of Main Pollutants of Various New Energy Buses. Automobile \& Parts Technology, No. 52, 16-20. (In Chinese)

Ou, X., Zhang, X., \& Chang, S. (2010). Scenario Analysis on Alternative Fuel/Vehicle for China's Future Road Transport: Life-Cycle Energy Demand and GHG Emissions. Energy Policy, 38, 3943-3956. https://doi.org/10.1016/j.enpol.2010.03.018

Pasaoglu, G., Honselaar, M., \& Thiel, C. (2012). Potential Vehicle Fleet $\mathrm{CO}_{2}$, Reductions and Cost Implications for Various Vehicle Technology Deployment Scenarios in Europe. Energy Policy, 40, 404-421. https://doi.org/10.1016/j.enpol.2011.10.025

Quah, E., \& Boon, T. L. (2003). The Economic Cost of Particulate Air Pollution on Health in Singapore. Journal of Asian Economics, 14, 73-90. https://doi.org/10.1016/S1049-0078(02)00240-3

Saikawa, E., Kurokawa, J., Takigawa, M. et al. (2011). The Impact of China's Vehicle Emissions on Regional Air Quality in 2000 and 2020: A Scenario Analysis. Atmospheric Chemistry \& Physics, 11, 267-72.

Shang, Y. et al. (2013). Systematic Review of Chinese Studies of Short-Term Exposure to Air Pollution and Daily Mortality. Environment International, 54, 100-111. https://doi.org/10.1016/j.envint.2013.01.010

Thomas, C. E. S. (2009). Transportation Options in a Carbon-Constrained World: Hybrids, Plug-In Hybrids, Biofuels, Fuel Cell Electric Vehicles, and Battery Electric Vehicles. International Journal of Hydrogen Energy, 34, 9279-9296. https://doi.org/10.1016/j.ijhydene.2009.09.058

Wang, R. J. (2015). Fuel-Cycle Assessment of Energy: An Environmental Impact from 
Electric Vehicles and Natural Gas Vehicles. Beijing: Tsinghua University. (In Chinese)

Wu, D., Xin, J.-Y., Sun, Y. et al. (2010). Change and Analysis of Background Concentration of Air Pollutants in North China during 2008 Olympic Games. Environmental Science, 31, 1130-1138. (In Chinese)

Xie, X. X. (2011). The Value of Health: Control Strategy of Environmental Benefit Assessment and Urban Air Pollution. Beijing: Peking University. (In Chinese)

Yan, X., \& Crookes, R. J. (2009). Reduction Potentials of Energy Demand and GHG Emissions in China's Road Transport Sector. Energy Policy, 37, 658-668. https://doi.org/10.1016/j.enpol.2008.10.008

Zhang, Y., Wang, S. G., Xia, Y. et al. (2015). Association between Ambient Air Pollution and Hospital Emergency Admissions for Respiratory and Cardiovascular Diseases in Beijing: A Time Series Study. Biomedical and Environmental Sciences, 28, 352-363. 